\title{
Új, sejtosztódást gátló neo- és szeszkvineolignánok taxon-specifikus felhalmozódása Cirsium fajok terméseiben
}

$\underline{K o ̈ n y e ~ R i t a ~}^{1,2}$, Tóth Gergö ${ }^{3}$, Sólyomváry Anna ${ }^{1}$, Mervai Zsolt ${ }^{4}$, Alberti Ágnes ${ }^{1}$, Béni Szabolcs ${ }^{1}$, Boldizsár Imre

${ }^{1}$ Semmelweis Egyetem, Farmakognóziai Intézet, 1085 Budapest, Üllői út 26.

${ }^{2}$ Eötvös Lóránd Tudományegyetem, Növényszervezettani Tanszék, 1117 Budapest, Pázmány Péter sétány $1 / C$.

${ }^{3}$ Semmelweis Egyetem, Gyógyszerészi Kémiai Intézet, 1092 Budapest, Hőgyes Endre utca 7.

${ }^{4}$ Semmelweis Egyetem, I.sz. Patológiai és Kísérleti Rákkutató Intézet, 1085 Budapest, Üllői út 26.

A lignán (Li), neolignán (NeLi) és szeszkvineolignán (SzeNeLi) másodlagos növényi anyagcseretermékek között értékes, sejtosztódást gátló hatóanyagokat is találunk, melyek hatásosságát már több daganatos sejtvonalon bizonyították. Korábbi eredményeink alapján a Cirsium (aszat) fajok termései nagy mennyiségben halmoznak fel ilyen típusú vegyületeket.

Jelen munkánk célja az eddig még nem vizsgált Cirsium fajok terméseinek fitokémiai jellemzése, különös tekintettel a lignánokra.

A C. rivulare (csermelyaszat) termésében két új természetes vegyületet (a NeLi demetilbalanofonint és a SzeNeLi demetilpikrazmalignánt) azonosítottunk. A nemzetség több fajának termésösszetételét összehasonlítva a Li, NeLi és SzeNeLi szerkezetű vegyületek taxonspecifikus felhalmozódását sikerült kimutatni. Ennek segítségével kiválasztásra kerültek azon Cirsium fajok, amelyek terméséből a lignánok magas hozammal, tiszta formában izolálhatók. Így a $C$. rivulare terméseiből a két új NeLi és SzeNeLi összetevőt (melyek a Cirsium nemzetség Chamaeleon szekciójára jellemzők), míg $C$. eriophorum terméseiből már ismert két NeLi-t (balanofonint és prebalanofonint) és két SzeNeLi-t (pikrazmalignánt és prepikrazmalignánt) nyertük ki. A prebalanofonin és a prepikrazmalignán az Eriolepis szekció jellemző vegyületeinek bizonyultak.

Kimutattuk továbbá az izolált vegyületek sejtosztódásgátló hatását (SW480 vastagbél adenokarcinóma sejtvonalon), valamint a szerkezet-hatás összefüggéseket állapítottunk meg.

Témavezetők: Béni Szabolcs (SE, Farmakognóziai Intézet)

Boldizsár Imre (ELTE, Növényszervezettani Tanszék) 